\title{
Kedudukan Manusia Sebagai Subyek Pembangunan di Bidang Kesehatan
}

\author{
Dini (70200120015) \\ Kesehatan Masyarakat \\ Fakultas Kedokteran dan Ilmu Kesehatan \\ UIN ALAUDDIN MAKASSAR \\ Email : dinyyy95@gmail.com
}

\begin{abstract}
Abstark
Dalam negara yang sedang berkembang terdapat siklus keadaan yang merupakan suatu lingkaran yang tak berujung, yang menghambat perkembangan masyarakat secara keseluruhan. Masalah kesehatan masyarakat di Indonesia umumnya disebabkan karena Rendahnya Tingkat Sosial Ekonomi masyarakat yang mengakibatkan Ketidakmampuan dan Ketidaktahuan dalam berbagai hal khususnya dalam bidang kesehatan dan perawatan dalam memelihara diri mereka sendiri ( Self Care ). Bila keadaan ini dibiarkan akan menyebabkan masalah kesehatan terhadap individu, keluarga, kelompok - kelompok dan masyarakat secara keseluruhan. Dan sebagai dampaknya adalah menurunnya Status Kesehatan Keluarga dan Masyarakat secara keseluruhan. Keadaan ini akan sangat berpengaruh terhadap Produktivitas keluarga dan masyarakat untuk menghasilkan sesuatu dalam memenuhi kebutuhan hidupnya, yang selanjutnya membuat kondisi sosial ekonomi keluarga dan masyarakat semakin rendah.

Adam Curle (1970) ahli pengembangan masyarakat berpendapat bahwa : Sumber - sumber keterbelakangan masyarakat bukan terletak pada kurangnya pendayagunaan sumber - sumber ekonomi, tetapi pada penggunaan yang salah dari sumber daya manusiawi ( ..... the wrong use of people.......). Dalam masyarakat itu sendiri sebenarnya terdapat suatu dinamika yang membuat mereka mampu bertahan dalam keadaan yang sulit dan hal itu sebenarnya merupakan potensi yang dapat dikembangkan untuk meningkatkan taraf hidupnya. Sampai seberapa jauh potensi itu telah berkembang, dapat dilihat dari keadaan perkembangan masyarakat itu sendiri. Pada masyarakat yang sudah berkembang, maka hal ini menunjukkan bahwa mereka telah dapat memanfaatkan potensi yang mereka miliki ; Sedangkan pada masyarakat yang belum berkembang berarti mereka belum banyak memanfaatkan potensi yang mereka miliki.
\end{abstract}




\section{A. Pendahuluan}

Pengorganisasian dan Pengembangan Masyarakat dilihat sebagai salah satu "tehnologi" dalam kegiatan Pendidikan Kesehatan sehingga terjadi perubahan perilaku sasaran (dalam bentuk kemampuan untuk mandiri atau self-help) yang sifatnya berkelanjutan untuk tercapainya derajat kesehatan yang lebih baik. Minat pokok dalam Promosi Kesehatan dalam konteks kesehatan masyarakat adalah masalah perubahan perilaku kesehatan. Minat pokok ini yang menjadi ciri khas Promkes yang membedakannya dari "disiplin keilmuan" lain dibidang kesehatan masyarakat. Dengan titik tolak pada minat pokoknya mengenai hal-hal yang berkaitan dengan proses perubahan perilaku, dengan menggunakan kerangka yang dikembangkan oleh Lawrence Green, Penggorganisasian dan Pengembangan Masyarakat merupakan tehnologi yang digunakan untuk melakukan intervensi pada faktor pendukung (enabling factors) sebagai salah satu prasyarat untuk terjadinya proses perubahan perilaku. Teknologi dalam Penggorganisasian dan Pengambangan Masyarakat diperuntukkan dalam pengorganisasian dan pengembangan sumber daya yang ada pada masyarakat sehingga mampu mandiri untuk meningkatkan derajat kesehatannya.

Upaya kesmas dilaksanakan melalui upaya masyarakat yang terorganisir. Penanggulangan penyakit dan peningkatan derajat kesehatan masyarakat tidak bisa dilakukan melalui upaya perorangan, tetapi harus melalui upaya bersama dan dilaksanakan secara berkelanjutan (jangka panjang). Upaya jangka panjang tidak bisa hanya mengandalkan tenaga kesehatan tetapi harus dilandasi keterlibatan aktif masyarakat melalui serangkaian upaya yang bersifat edukatif untuk membentuk perilaku sehat,

Penggunaan istilah Pengorganisasian dan Pengembangan Masyarakat diambil dari konsep Pengorganisasian Masyarakat (Community Organization) dan Pengembangan Masyarakat (Community Development). Istilah Community Organization terutama lebih banyak muncul dalam kepustakaan yang berasal dari atau berkiblat pada Amerika Serikat sedangkan Community Development" lebih banyak ditemukan dalam 
kepustakaan yang berasal atau berkiblat dari Inggris. Meskipun "nama"nya berbeda, tetapi isi dan konsepnya adalah sama. Keduanya berorientasi pada proses menuju tercapainya kemandirian melalui keterlibatan atau peran serta aktif dari keseluruhan anggota masyarakat.

\section{B. Kedudukan Manusia Sebagai Subyek Pembangunan di Bidang Kesehatan}

- Hakikat manusia dan pandangan psikonalitik humanistic dan behaviolistik

Hakikat manusia adalah sebagai gagasan atau konsep yang mendasari manusia dan eksistensinya di dunia. Eksistensinya berhubungan dengan masa lalunya untuk menjangkau masa depan untuk mencapai tujuan dalam hidupnya. Manusia berada dalam perjalanan hidup, perkembangan dan pengembangan diri namun, manusia disini belum tuntas mewujudkan dirinya sebagai manusia. Pendidikan pada dasarnya adalah upaya untuk memanusiakan manusianya. Manusia sudah dibekali berbagai potensi untuk mampu menjadi manusia. Kemampuannya itu hanya dapat dilakukan setelah kelahirannya dalam perkembangan menuju kedewasaanya dan tidak di bawa sejak kelahirannya. Pendidikan sebagai proses untuk mengubah sikap dan perilaku manusia. Manusia memiliki kesadaran dan penyadaran diri yang mampu membedakan dirinya dengan segala sesuatu yang ada di luar dirinya. Manusia juga tidak hanya mampu berpikir mengenai diri dan alam akan tetapi juga sadar dengan pemikirannya.

Manusia memiliki Hasrat untuk mengetahui. Pendidikan juga berfungsi untuk menyadarkan manusia agar manusia mampu mengenal, melihat dan memahami realitas kehidupan yang ada di sekelilingnya. Manusia perlu mendidik diri karena manusia sebagai mahkluk yang disebut Animal Educable. Manusia yang bereksistensi harus dapat menjadikan diri itu hakikatnya adalah manusia itu sendiri. Jadi, sebaik dan sekuat upaya pihak lain atau 
pendidik kepada peserta didik untuk membantunya menjadi manusia, akan tetapi apabila peserta didiknya tidak ingin mendidik dirinya sendiri maka upaya bantuan tersebut tidak akan memberikan kontribusi bagi kemungkinan manusia tadi untuk menjadi manusia. Hakikat manusia sebagai berikut.

1. Sebagai makhluk social

2. Eksistensi atau memiliki metode hidup

3. Memiliki gagasan

4. Peka terhadap kesekelilingnya

- Kedudukan Kelompok Sasaran Sebagai Subyek dan Obyek Pembangunan Kesehatan

Ini dikaitkan dengan pandangan tentang hakekat manusia yang bersifat psiko -analitik, humanistik dan behavioristik. Dalam kaitan ini juga dibahas perkembangan pendekatan dalam program kesehatan masyarakat dimana terjadi pergeseran dari pendekatan yang bersifat doing things to and for people menjadi doing things with people. Dalam menempatkan kelompok sasaran sebagai subyek kegiatan, dibahas juga tentang konsep "piring terbang", dimana upaya meningkatkan kesejahteraan masyarakat terutama dilihat sebagai upaya peningkatan dinamika mereka sendiri yang terwujudkan dalam efek "tinggal landas" (upward spirall movement). Intervensi luar dalam konsep ini harus menyesuaikan diri dengan kecepatan perputaran "piringan" dinamika masyarakat yang ada agar tidak timbul kegoncangan masyarakat.

- Proses belajar/Pendidikan dalam program Kesehatan

Seperti yang telah disebutkan sebelumnya, tujuan yang ingin dicapai dalam Pengorganisasian dan Pengembangan Masyarakat adalah diperolehnya kemandirian masyarakat untuk meningkatkan derajat kesehatan. Untuk mencapai tujuan ini maka kegiatan kegiatan yang dilakukan dalam upaya PPM harus diarahkan pada diperolehnya pengalaman belajar dari kelompok sasaran. Akumulasi 
dari pengalaman belajar yang diperoleh secara bertahap ini kemudian akan menghasilkan kemampuan menolong diri sendiri dalam meningkatkan derajat kesehatannya. Dalam bahasan ini dibicarakan tentang tiga situasi belajar dalam masyarakat, yaitu required outcome situation, recommended outcome situation dan self-directed outcome situation.

1. Situasi yang diwajibkan (required outcome situation)suatu proses belajar yang hasilnya benar-benar dikehendaki/diwajibkan/dipaksa tatkala terdapat situasi di mana suatu perubahan perilaku/tindakan tertentu benarbenar dibutuhkan individu/sekelompok individu. Tipe belajar ini biasanya dilakukan petugas kesehatan ketika menemukan situasi gawat darurat.

2. Situasi yang disarankan (recommended outcome situation)Adalah situasi yang membolehkan untuk memilih tanpa ada paksaan dan bertujuan untuk memberikan informasi, menyadarkan, menasihati orang dan mendorong masyarakat untuk melakukan penilaian sendiri terhadap kegunaan dari program yang disarankan. Dengan catatan perlu adanya peningkatan pengetahuan dan keterampilan petugas kesehatan. Contoh adalah alat kontrasepsi berikut dengan pilihannya.

3. Situasi yang ditetapkan sendiri (self-directed outcome situation). Self-Directed Programme adalah suatu proses belajar yang bertujuan untuk membantu masyarakat dalam uasaha mereka mencari informasi, mengevaluasi, merencanakan dan menyusun program mereka sendiri. Bantuan itu berupa: petunjuk, pengarahan, bimbingan dan saran kepada masyarakat.

- Perkembangan Pendekatan Kesehatan Masyarakat yang Berorientasi pada Petugas Masyrakat 
Dengan bertitik tolak dari pengertian tentang Pengembangan Masyarakat seperti yang telah diuraikan tersebut di atas, maka masyarakat merupakan Subyek dari kegiatan yang menjadi sasaran kegiatan. Peranan lembaga dari luar hanyalah sebagai perangsang agar proses yang terjadi berjalan secara optimal. Dengan demikian, maka Penjabarannya secara Operasional dilaksanakan dengan cara :

a. Berikan kesempatan agar masyarakat sendiri yang menentukan masalah kesehatannya, baik yang dihadapi secara individu, keluarga, kelompok maupun masyarakat.

b. Berikan kesempatan agar masyarakat sendiri yang membuat analisa dan kemudian menyusun perencanaan penanggulangan masalah.

c. Berikan kesempatan agar masyarakat sendiri yang mengorganisir diri untuk melaksanakan usaha perbaikan tersebut.

d. Dalam proses ini sedapat mungkin digali sumber - sumber daya yang ada dalam masyarakat sendiri dan kalau betul betul diperlukan dimintakan bantuan dari luar.

Dengan menjadikan masyarakat sebagai Subyek kegiatan, maka Tujuan yang ingin dicapai dalam Pengembangan Masyarakat adalah

1. Menumbuhkan rasa percaya pada diri sendiri.

2. Menimbulkan rasa bangga, semangat dan gairah kerja

3. Meningkatkan dinamika masyarakat untuk membangun

4. Meningkatkan kesejahteraan masyarakat.

\section{Kesimpulan}

Hakikat manusia adalah seperangkat gagasan atau konsep yang mendasar tentang manusia dan makna eksistensi manusia di dunia. 
Berkenaan dengan "prinsip adanya" (principe de 'ere) manusia. Manusia adalah kesatuan badani rohani, hidup dalam ruang dan waktu, sadar akan diri dan lingkungannya, mempunyai berbagai kebutuhan, insting, nafsu, dan tujuan hidup. Hakikat manusia adalah makhluk yang memiliki tenaga dalam yang dapat menggerakkan hidupnya untuk memenuhi kebutuhankebutuhannya. Individu yang memiliki sifat rasional yang bertanggung jawab atas tingkah laku intelektual dan sosial. Manusia yang mampu mengarahkan dirinya ke tujuan yang positif mampu mengatur dan mengontrol dirinya dan mampu menentukan nasibnya.

\section{DAFTAR PUSTAKA}

Desak Putu Yuli Kurniati. (2015). BAHAN AJAR PENGORGNISASIAN DAN PENGEMBANGAN MASYRAKAT. Udayana.

Keiko Dodo Guhal. (n.d.). Hakikat Manusia dalam Mendidik Diri dan Pendidikan sebagai Humanisasi. 7. 